\title{
MODELING THE MAXIMAL ORGANIC CARBON SATURATION CAPACITY IN KARST FOREST SOILS OF CHINA: COMPARING THE EXISTING MODELS
}

\author{
ZHANG, L. M. ${ }^{1,2}-$ WU, Y. N. ${ }^{1}-$ YAN, L. B. $^{1}-$ WANG, Y. ${ }^{1}-$ CHEN, J. ${ }^{1}$-YU, L. F. ${ }^{*}$ \\ ${ }^{1}$ Research Center of Karst Ecological Environment, the Key laboratory of Plant Resource \\ Conservation and Germplasm Innovation in Mountainous Region (Ministry of Education) / \\ Collaborative Innovation Center for Mountain Ecology \& Agro-Bioengineering, College of Life \\ Sciences / Institute of Agro-bioengineering, Guizhou University, Guiyang 550025, Guizhou \\ Province, China \\ (e-mail: zhanglimin563406@163.com (Zhang,L.M.);YnWU123@163.com (Wu,Y.N.); \\ gdsky@ylfylb (Yan, L. B.); gdwyang2020@163.com (Wang, Y.); gs.chenjin20@gzu.edu.cn \\ (Chen, J.)) \\ ${ }^{2}$ Institute of Guizhou Mountain Resources, Guizhou Academy of Scieinces, Guiyang 550001, \\ Guizhou Province, China \\ (e-mail: zhanglimin563406@163.com (Zhang, L.M.)) \\ ${ }^{*}$ Corresponding author \\ e-mail:lfyu@gzu.edu.cn
}

(Received $26^{\text {th }}$ May 2021; accepted $4^{\text {th }}$ Sep 2021)

\begin{abstract}
Karst forests are special and complex, featuring soil that typically exists as a thin layer, with a low $\mathrm{C}($ Carbon) storage capacity but is rich in calcium and alkali. However, the maximum saturated capacity of the soil organic carbon (SOC) remains unclear. To address this crucial knowledge gap, a total of 10 typical karst forest (climax communities) topsoil samples of China were investigated using SOC fractionation methods, for which a maximum saturated capacity model of SOC was derived via leastsquares linear regression (LSR) and boundary line analysis (BL). For our data, we found that the oversaturated proportion (the actual measured carbon content is greater than estimated by the model) of organic $\mathrm{C}$ data according to the Hassink model $(\mathrm{y}=0.37 \mathrm{x}+4.09), \operatorname{LSR}(\mathrm{y}=0.35 \mathrm{x}+6.83)$, and the Feng model $(y=1.07 x)$ were $56.7 \%, 40.0 \%$, and $16.7 \%$, respectively, while that according to the BL model $(y=1.30 x)$ was only $3.3 \%$. This comparative analysis, based on validations with a robust sample size $(\mathrm{N}=30)$, shows that the Hassink model, LSR, and Feng model all performed poorly at estimating the maximal organic $\mathrm{C}$ saturation capacity in karst forest, in contrast to the BL model $(\mathrm{y}=1.30 \mathrm{x})$, which is more suitable and accurate.
\end{abstract}

Keywords: climax communities, boundary line analysis, least-square linear regression, soil organic carbon, soil fine particles

\section{Introduction}

The soil carbon pool is critical for the global $\mathrm{C}$ cycle because it is the largest $\mathrm{C}$ pool within the surface $(0-20 \mathrm{~cm})$ of terrestrial ecosystems, of which forests are vital components (Trumbore et al., 2006; Banger et al., 2009). Globally, forest ecosystem soils 
collectively store $40 \%$ of the organic $\mathrm{C}$ in the top $0-1 \mathrm{~m}$ soil layer, and its accumulation and decomposition processes directly impact the global C balance (Schlesinger, 1990; Ding et al., 2012; Zhu et al., 2017; Chen et al., 2019; Liu et al., 2020). Therefore, the size and dynamics of the forest SOC pool within the global C cycle and under ongoing climate change is particularly important (Dixon et al., 1994; Houghton et al., 2001; Pan et al., 2005).

Karst forest is a distinctive ecosystem type, especially those located in southwest China, which reside in a subtropical monsoon climate, where the soluble carbonate rocks result in slow soil formation, thereby generating soil rich in calcium and alkali that differs starkly from that in non-karst areas. Accordingly, the relationship between calcium carbonate in soil and karst SOC directly affects the maintenance of the karst forest ecosystems (Su et al., 2015; Hu et al., 2016), imparting with specific features regarding soil C cycling (Lu et al., 2014; Wang et al., 2015; Li et al., 2017). Therefore, it is of great significance to study how the SOC pool is balanced in karst forest.

Many studies find that SOC fractions show different response mechanisms under levels of long-term exogenous C input. For example, Stewart et al. $(2008,2009)$ showed that with an increased $\mathrm{C}$ input level, non-protected organic $\mathrm{C}$ and physically protected organic $\mathrm{C}$ exhibit a linear growth trend, while chemically protected organic $\mathrm{C}$ and biochemically protected organic $\mathrm{C}$ followed a "curve saturation" growth trend. In other works, by Six et al. (2002), West et al. (2007), Chung et al. (2008, 2010), and Luo et al. (2020), it was found that small aggregate organic $\mathrm{C}(<20 \mu \mathrm{m})$ also showed a "curve" increase with more $\mathrm{C}$ inputs into soil. This phenomenon was defined by Stewart et al. (2008) as "soil C saturation"; that is, after putting a certain amount of exogenous C into the soil, the SOC will increase over time until it reaches a state of dynamic equilibrium, where the total level of soil $\mathrm{C}$ input equals that of $\mathrm{C}$ release. However, should new $\mathrm{C}$ sources be continually injected into the soil, this delicate $\mathrm{C}$ balance will likely become disrupted and this effect will intensify and persist through time, perhaps reaching a new stable state. However, if exogenous $\mathrm{C}$ is continually added yet the SOC remains unchanged, the type of balance is termed "soil C saturation," that is, the maximum $\mathrm{C}$ capacity of the soil has been attained (West et al., 2007; Rillig et al., 2019; Jing et al., 2020).

In an earlier work, Hassink (1997) compared the stable C content of natural grassland and cultivated soil, finding the former had a higher organic $\mathrm{C}$ content driven by $>20 \mu \mathrm{m}$ soil particles, since there was no difference in the organic $\mathrm{C}$ content of $<20 \mu \mathrm{m}$ particles between the two kinds of soil. Therefore, the protection capacity of fine particles for organic $\mathrm{C}$ was proposed, that is, fine particle organic $\mathrm{C}$ is stable organic $\mathrm{C}$, and the capacity is limited. On this basis, by collecting data and focusing on fine particle $\mathrm{C}$ with relatively stable $\mathrm{C}$ sequestration in soil, many researchers generated empirical models and parameter indexes for predicting the saturated capacity of SOC, which could be used to estimate the turnover rate of SOC and the $\mathrm{C}$ saturation deficit in a specific region (Williams et al., 1974; Hassink, 1997; Six et al., 2002; Liang et al., 2009; Feng et al., 
2013; Di et al., 2018). For example, Hassink (1997) used least-squares linear regression (LSR) to obtain a simple straightforward model for estimating the saturated capacity of fine particle organic $\mathrm{C}$, namely $\mathrm{y}=0.37 \mathrm{x}+4.09$, where $\mathrm{x}$ is the mass proportion of the $<20 \mu \mathrm{m}$ fine particles. This empirical model has since been widely used (Angers et al., 2011; Zhang et al., 2014; Guo et al., 2016; Bastida et al., 2019). Later, Feng (2013) made a comparative study of grassland, cultivated land, and forest soils, uncovering some shortcomings of the Hassink model. The estimation of the maximum saturated capacity of SOC was improved by instead applying a boundary line (BL), thus providing a model specific for forests taking the form of $\mathrm{y}=1.07 \mathrm{x}$ (where $\mathrm{x}$ is the mass ratio (proportion) of $<20 \mu \mathrm{m}$ fine particles).

In the karst forest region of China, we previously compared with the research objects of Hassink and Feng, the regional location, soil type and climatic conditions are different, so whether the model can be used to estimate the maximum saturated capacity of SOC in karst forest of China remains to be further verified. Therefore, the primary research questions addressed in the present study are: Is the Hassink model or Feng model suitable for estimating the maximum saturated capacity of SOC in the karst forests of China? If neither is suitable, how might we construct an improved model to predict the maximum saturated capacity of SOC?

\section{Materials and methods}

\section{Field investigation and soil sample collection}

Based on multiple field investigations and our working experience, 10 climax communities having the oldest forest stands and the least disturbance were selected for study in a typical karst area of Guizhou Province in China. The 10 sites were the Maolan national nature reserve ('Maolan'), Daozhen dashahe nature reserve ('Dashahe'), Shibing yuntai mountain nature reserve ('Yuntai mountain'), Nayong gongtong nature reserve ('Nayong'), Pogang karst vegetation nature reserve ('Pogang'), Suiyang kuankuoshui nature reserve (Kuankuoshui), Puding huoyan mountain nature reserve ('Huoyan mountain'), Jiangkou huanggu mountain nature reserve ('Huanggu mountain'), Kaiyang zijiang rift valley ('Zijiang rift valley'), and Wangmo bijia mountain ('Bijia mountain'); all locations are shown in Figure 1.

In December 2019, a minimum sampling area of $900 \mathrm{~m}^{2}(30 \mathrm{~m} \times 30 \mathrm{~m})$ was determined by drawing a "species-area curve". Three sampling plots were constructed in each climax community, for which the longitude and latitude, slope aspect, slope, soil type and altitude were recorded, in addition to determining the dominant plant species names as well as the abundance (counts), height, crown width, coverage, and DBH (diameter at breast height [1.3 m]) of individual trees (Table 1). In addition, from each site, one composite soil samples (one per plot) were taken from the surface layer $(0-20 \mathrm{~cm}$ depth). These samples were then sieved through $2 \mathrm{~mm}$ and $0.25 \mathrm{~mm}$ mesh screens; any roots and stubble were removed, and 30 samples (There were 10 climax communities, each climax community 
was set with 3 plots, and 1 soil samples were collected in each plot) were analyzed separately.

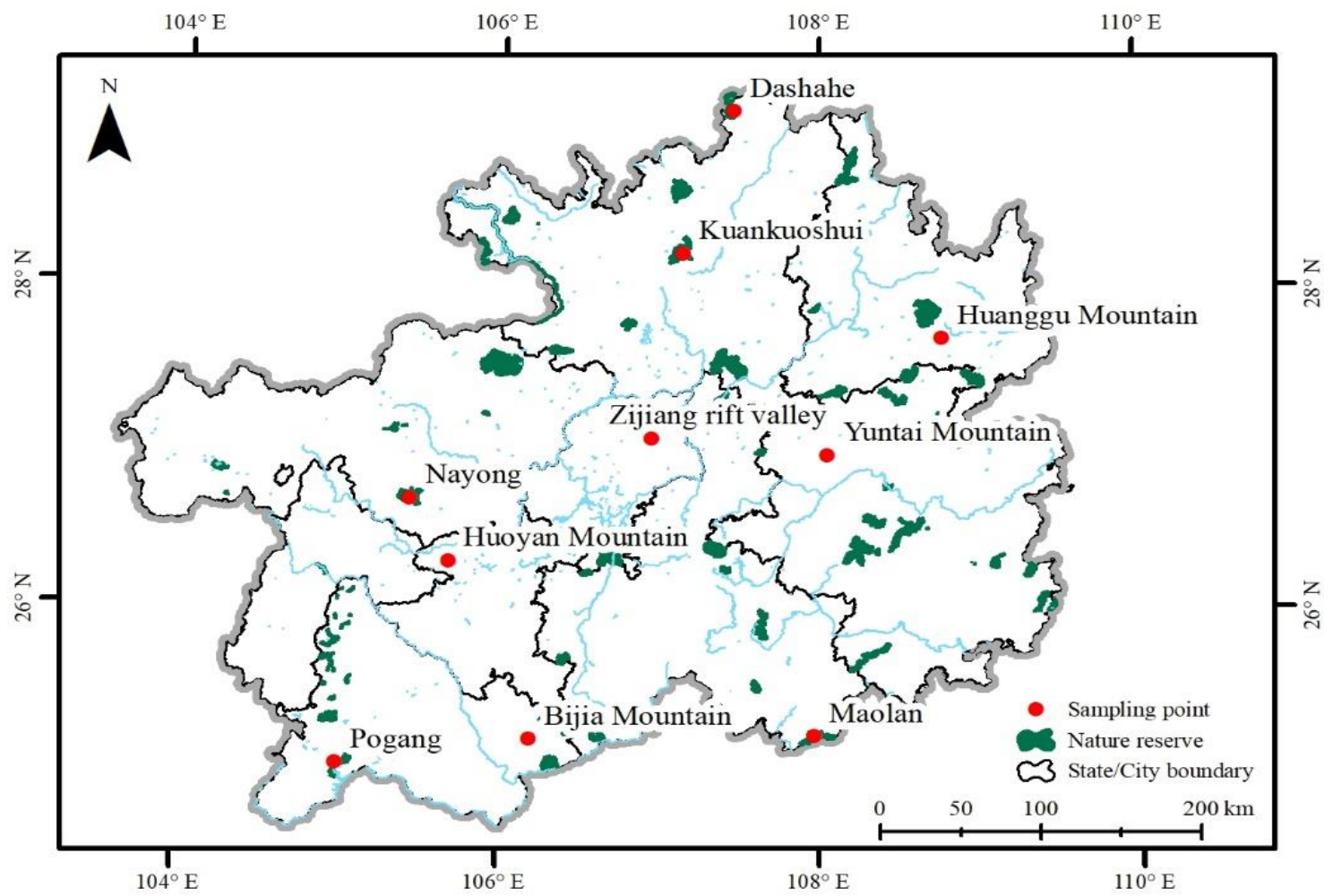

Figure 1. Geographical map showing the locations in Guizhou Province (China) of the sampled karst forest sites

\section{Soil fractionation and $C$ analyses}

Six et al. (2002) divided SOC fractionation into three size fractions by wet sievingisolation of microaggregates: $>250 \mu \mathrm{m}$ (coarse particles), $53-250 \mu \mathrm{m}$ (microaggregate), and $<53 \mu \mathrm{m}$ (fine particles). Each soil subsample $(20 \mathrm{~g})$ was placed on a $250 \mu \mathrm{m}$ sieve and carefully shaken with 30 glass beads on the top of the microaggregate isolator containing water filled to two-thirds of its volume. After $20 \mathrm{~min}$, the fraction corresponding to the $>250 \mu \mathrm{m}$ particle size and that fraction whose particles had a size between 250 and $53 \mu \mathrm{m}$ were collected in an aluminum specimen box. The remaining suspension harboring the $<53 \mu \mathrm{m}$ size and water was flocculated with $20 \mathrm{~mL}$ of $\mathrm{CaCl}_{2}$ $(0.25 \mathrm{M})$ and centrifuged at $127 \times \mathrm{g}$ for $7 \mathrm{~min}$, to separate and isolate the fine particle fraction. All three fractions were dried at $60^{\circ} \mathrm{C}$, weighed, and stored. Their respective SOC was determined using the potassium dichromate method. The fractionation and respective determinations of SOC were repeated three times for each soil sample. 
Table 1. Basic information on the environmental background of different sampled sites for karst forest in China

\begin{tabular}{|c|c|c|c|c|c|c|c|c|}
\hline $\begin{array}{l}\text { Sampling point } \\
\text { site }\end{array}$ & $\begin{array}{l}\text { Vegetational } \\
\text { form }\end{array}$ & Location & $\begin{array}{c}\text { Elevation, } \\
\text { longitude \& } \\
\text { latitude }\end{array}$ & $\begin{array}{l}\text { Slope aspect } \\
\text { and position }\end{array}$ & Dominant tree species & $\begin{array}{c}\text { Soil } \\
\text { bedrock }\end{array}$ & Soil type & $\begin{array}{l}\text { Total } \\
\text { cover } \\
\text { extent }\end{array}$ \\
\hline Maolan & $\begin{array}{l}\text { Climax } \\
\text { vegetation }\end{array}$ & $\begin{array}{l}\text { Baixian } \\
\text { mountain }\end{array}$ & $\begin{array}{c}850 \mathrm{~m} \\
107.99,25.19\end{array}$ & $\begin{array}{l}\text { Southwest } \\
\text { central }\end{array}$ & $\begin{array}{l}\text { Carpinus pubescens, Swida wilsoniana, } \\
\text { Pittosporum brevicalyx, Cyclobalanopsis } \\
\text { multiervis, Acer wangchii }\end{array}$ & $\begin{array}{l}\text { Dolomite } \\
\text { limestone }\end{array}$ & $\begin{array}{l}\text { Limestone } \\
\text { soil }\end{array}$ & $89.45 \%$ \\
\hline Dashahe & $\begin{array}{c}\text { Climax } \\
\text { vegetation }\end{array}$ & Shahe & $\begin{array}{c}1304 \mathrm{~m}, \\
107.58 \& 29.17\end{array}$ & North central & $\begin{array}{c}\text { Machilus pingii,Fagus longipetiolata, } \\
\text { Pistacia chinensis Bunge, Lindera } \\
\text { communis }\end{array}$ & $\begin{array}{c}\text { Carbonate } \\
\text { rock }\end{array}$ & $\begin{array}{l}\text { Limestone } \\
\text { soil }\end{array}$ & $88.32 \%$ \\
\hline Yuntai $\mathrm{m}$ & $\begin{array}{c}\text { Climax } \\
\text { vegetation }\end{array}$ & $\begin{array}{l}\text { Yuntai } \\
\text { mountain }\end{array}$ & $\begin{array}{c}875 \mathrm{~m} \\
108.11 \& 27.12\end{array}$ & $\begin{array}{l}\text { Northwest } \\
\text { central }\end{array}$ & $\begin{array}{c}\text { Machilus pingii, Pistacia chinensis Bunge, } \\
\text { Acer cordatum Pax }\end{array}$ & $\begin{array}{c}\text { Carbonate } \\
\text { rock }\end{array}$ & $\begin{array}{l}\text { Limestone } \\
\text { soil }\end{array}$ & $85.74 \%$ \\
\hline Nayong & $\begin{array}{l}\text { Climax } \\
\text { vegetation }\end{array}$ & $\begin{array}{l}\text { Jinzhulin } \\
\text { village }\end{array}$ & $\begin{array}{c}1861, \mathrm{~m} \\
105.44 \& 26.68\end{array}$ & $\begin{aligned} \text { Nort } \\
\text { cer }\end{aligned}$ & $\begin{array}{c}\text { Davidia involucrata, Decaisnea insignis, } \\
\text { Dipentodon sinicus, Cyclobalanopsis } \\
\text { argyrotricha }\end{array}$ & $\begin{array}{c}\text { Carbonate } \\
\text { rock }\end{array}$ & $\begin{array}{l}\text { Limestone } \\
\text { soil }\end{array}$ & $87.96 \%$ \\
\hline Pogang & $\begin{array}{c}\text { Climax } \\
\text { vegetation }\end{array}$ & Minzu village & $\begin{array}{c}1280 \mathrm{~m} \\
105.09 \& 25.11\end{array}$ & North central & $\begin{array}{c}\text { Eucalyptus robusta, Platycarya strobilacea, } \\
\text { Itoa orientalis Hemsl }\end{array}$ & $\begin{array}{l}\text { Dolomite } \\
\text { limestone }\end{array}$ & $\begin{array}{l}\text { Limestone } \\
\text { soil }\end{array}$ & $86.63 \%$ \\
\hline Kua & $\begin{array}{c}\text { Climax } \\
\text { vegetation }\end{array}$ & Matixi & $\begin{array}{c}1450 \mathrm{~m} \\
107.06 \& 28.18\end{array}$ & $\begin{array}{l}\text { Southwest } \\
\text { central }\end{array}$ & $\begin{array}{c}\text { Fagus longipetiolata, Emmenopterys henryi, } \\
\text { Tulip poplar }\end{array}$ & $\begin{array}{c}\text { Carbonate } \\
\text { rock }\end{array}$ & $\begin{array}{l}\text { Limestone } \\
\text { soil }\end{array}$ & $91.34 \%$ \\
\hline Huo & $\begin{array}{r}\text { Clir } \\
\text { veget }\end{array}$ & $\begin{array}{l}\text { Fenglin } \\
\text { huoyan } \\
\text { mountain }\end{array}$ & $\begin{array}{c}1680 \mathrm{~m} \\
105.79 \& 26.47\end{array}$ & West central & Rhododendron stamineum, Birch, Oak & $\begin{array}{c}\text { Carbonate } \\
\text { rock }\end{array}$ & $\begin{array}{l}\text { Limestone } \\
\text { soil }\end{array}$ & $90.17 \%$ \\
\hline Huanggu & $\begin{array}{c}\text { Climax } \\
\text { vegetation }\end{array}$ & Heitanggou & $\begin{array}{c}1020 \mathrm{~m} \\
108.78 \& 27.54\end{array}$ & North central & $\begin{array}{c}\text { Fagus longipetiolata, Buxus sinica, Davidia } \\
\text { involucrata, Hemlock }\end{array}$ & $\begin{array}{c}\text { Carbonate } \\
\text { rock }\end{array}$ & $\begin{array}{l}\text { Limestone } \\
\text { soil }\end{array}$ & $87.15 \%$ \\
\hline Huanggu mountain & $\begin{array}{c}\text { Climax } \\
\text { vegetation }\end{array}$ & Heitanggou & $\begin{array}{c}1020 \mathrm{~m} \\
108.78 \& 27.54\end{array}$ & North central & $\begin{array}{c}\text { Fagus longipetiolata, Buxus sinica, Davidia } \\
\text { involucrata, Hemlock }\end{array}$ & $\begin{array}{c}\text { Carbonate } \\
\text { rock }\end{array}$ & $\begin{array}{l}\text { Limestone } \\
\text { soil }\end{array}$ & $87.15 \%$ \\
\hline Zijiang 1 & $\begin{array}{c}\text { Climax } \\
\text { vegetation }\end{array}$ & Liangchahe & $\begin{array}{c}720 \mathrm{~m} \\
107.04 \& 26.90\end{array}$ & $\begin{array}{l}\text { Southwest } \\
\text { central }\end{array}$ & $\begin{array}{c}\text { Betula luminifera, Cinnamomum camphora, } \\
\text { Pistacia chinensis, Liquidenbar formosana }\end{array}$ & $\begin{array}{c}\text { Carbonate } \\
\text { rock }\end{array}$ & $\begin{array}{l}\text { Limestone } \\
\text { soil }\end{array}$ & $81.25 \%$ \\
\hline & $\begin{array}{l}\text { Climax } \\
\text { vegetation }\end{array}$ & Liangfengao & $\begin{array}{c}1083 \mathrm{~m} \\
106.14 \& 25.12\end{array}$ & $\begin{array}{l}\text { Northeast } \\
\text { central }\end{array}$ & $\begin{array}{l}\text { Cyclobalanopsis oak, Carpinus pubescens, } \\
\text { Celtis sinensis, Ormosia saxatilis }\end{array}$ & $\begin{array}{c}\text { Carbonate } \\
\text { rock }\end{array}$ & $\begin{array}{l}\text { Limestone } \\
\text { soil }\end{array}$ & $90.18 \%$ \\
\hline
\end{tabular}




\section{Data analysis}

Building on the original work of Hassink (1997), as well as more recent studies (Hassink, 1997; Six et al., 2000, 2002; Stewart et al., 2007, 2008, 2009, 2012; Feng et al., 2013), we applied several different methods to estimate the stabilization capacity of the fine particles, based on statistical analyses of the relationship between the $C$ contents of the fine particles and mass proportions. Combined with the karst site characteristics, the two classical modeling approaches (LSR and BL) were compared and analyzed. Through model verification, a model for estimating the maximum saturated capacity of SOC in karst forest was constructed.

The Hassink (1997) method is based on the LSR of the mass ratio of fine particles ( $\mathrm{g}$ fraction $100 \mathrm{~g}^{-1}$ soil) as a function of the SOC content of fine particles ( $\mathrm{mg} \mathrm{C} \mathrm{g}^{-1}$ soil); it is described as $\mathrm{y}=0.37 \mathrm{x}+4.09$, where $\mathrm{y}$ is the maximum $\mathrm{C}$ capacity that the soil can retain ( $\mathrm{mg} \mathrm{C} \mathrm{g}^{-1}$ soil), and $\mathrm{x}$ is the fine particles mass ratio ( $\mathrm{g}$ fraction $100 \mathrm{~g}^{-1}$ soil).

The BL method described by Feng (2013) was also applied herein to estimate the C stabilization capacity. The BL method is a statistical approach to define the upper limits of a dependent variable where there is evidence for a limiting response to an independent variable(s) along a defined boundary. Briefly, the method involves applying linear regression analysis to the upper-most (e.g., the top 10\%) values of fine fraction C content across a wide range of fine particle masses. This process involved sorting the data into nine groups based on the mass proportions of the soil fine particles, at intervals of $10 \mathrm{~g}$ fraction $100 \mathrm{~g}^{-1}$ soil, ranging from $<10$ to $>90 \mathrm{~g}$ fraction $100 \mathrm{~g}^{-1}$ soil. The upper $10 \%$ of soil $\mathrm{C}$ values in each group were identified and extracted along with the corresponding mass proportion data. These boundary line data were then subjected to a regression analysis where the y-intercept was forced through the origin, based on the assumptions outlined above. The forest model of Feng (2013) is $y=1.07 x$, where $y$ is the maximum organic $\mathrm{C}$ capacity that the soil can retain $\left(\mathrm{mg} \mathrm{C} \mathrm{g}^{-1}\right.$ soil), and $\mathrm{x}$ is the fine particles mass ratio ( $\mathrm{g}$ fraction $100 \mathrm{~g}^{-1}$ soil).

\section{Results}

\section{Changes to soil fine particles and total organic C}

Table 2 reports our analysis of the mass proportion and $\mathrm{C}$ content of soil fine particles as well as the total organic $\mathrm{C}$ content in 10 karst forest climax communities. The mass proportions of soil fine particles in Maolan, Yuntai mountain, and Zijiang rift valley were the highest, at 31.36, 28.61 and $26.31 \mathrm{~g}$ fraction $100 \mathrm{~g}^{-1}$ soil, respectively. However, both the $\mathrm{C}$ content of soil fine particles and total organic $\mathrm{C}$ content were greatest in Nayong, at $23.56 \mathrm{mg} \mathrm{C} \mathrm{g}^{-1}$ soil and $147.11 \mathrm{mg} \mathrm{C} \mathrm{g}^{-1}$ soil, respectively. There was no significant difference in the ratio of soil fine particles to total organic $\mathrm{C}$ among the 10 climax community sites. 
Table 2. Mass proportion of soil fine particles and proportion of organic $C$ content of the total organic C content in karst forest of the 10 nature reserves

\begin{tabular}{|c|c|c|c|c|}
\hline Sampling point site & $\begin{array}{c}\text { Mass proportion of } \\
\text { soil fine particles } \\
\text { (g fraction } 100 \mathrm{~g}^{-1} \\
\text { soil) }\end{array}$ & $\begin{array}{c}\text { Organic C content } \\
\text { of soil fine particles } \\
\left(\mathrm{mg} \mathrm{C}^{-1} \text { soil }\right)\end{array}$ & $\begin{array}{c}\text { Total organic } \mathrm{C} \\
\text { content } \\
\left(\mathrm{mg} \mathrm{C} \mathrm{g}^{-1} \text { soil) }\right.\end{array}$ & $\begin{array}{c}\text { Proportion of } \\
\text { organic C content } \\
\text { (g fraction } 100 \mathrm{~g}^{-1} \\
\text { soil) }\end{array}$ \\
\hline Maolan & $31.36 \pm 3.13 \mathrm{a}$ & $17.17 \pm 0.73 b$ & $94.31 b \pm 3.60$ & $18.28 \pm 0.67$ \\
\hline Dashahe & $22.05 \pm 1.27 \mathrm{c}$ & $15.52 \pm 1.46 b$ & $78.75 \mathrm{~cd} \pm 2.45$ & $19.45 \pm 1.36$ \\
\hline Yuntai mountain & $28.61 \pm 2.05 b$ & $16.10 \pm 2.48 b$ & $82.13 c \pm 5.01$ & $19.60 \pm 1.08$ \\
\hline Nayong & $18.17 \pm 2.95 d$ & $23.56 \pm 3.87 \mathrm{a}$ & $147.11 \mathrm{a} \pm 6.55$ & $18.42 \pm 0.52$ \\
\hline Pogang & $17.74 \pm 1.13 \mathrm{~d}$ & $15.44 \pm 1.43 b$ & $81.78 c \pm 8.89$ & $18.88 \pm 0.34$ \\
\hline Kuankuoshui & $22.99 \pm 1.32 \mathrm{c}$ & $11.45 \pm 0.28 \mathrm{c}$ & $59.50 \mathrm{de} \pm 4.79$ & $19.24 \pm 1.17$ \\
\hline Huoyan mountain & $16.65 \pm 2.69 d$ & $9.03 \pm 1.73 d$ & $49.43 \mathrm{e} \pm 0.63$ & $21.09 \pm 0.70$ \\
\hline Huanggu mountain & $22.26 \pm 1.41 \mathrm{c}$ & $15.62 \pm 1.77 b$ & $75.79 \mathrm{~cd} \pm 1.39$ & $20.61 \pm 2.26$ \\
\hline Zijiang rift valley & $26.31 \pm 1.72 b$ & $8.30 \pm 0.78 \mathrm{~d}$ & $42.05 \mathrm{f} \pm 1.85$ & $19.74 \pm 1.76$ \\
\hline Bijia mountain & $14.06 \pm 0.77 \mathrm{de}$ & $12.26 \pm 1.49 \mathrm{c}$ & $65.41 \mathrm{~d} \pm 6.03$ & $18.82 \pm 0.25$ \\
\hline
\end{tabular}

Different letters within a column indicate a significant difference $(\mathrm{P}<0.05)$ between the nature reserve sites. The $\mathrm{C}$ content and proportion are reported as the mean $\pm \mathrm{SE}$

\section{Regressions of organic C contents of soil fine particles against mass proportions}

The relationship between organic $\mathrm{C}$ content of soil fine particles and mass proportion in karst forest was fitted by the LSR and BL methods (Figure 2, Table 3), whose respective best-fitting functions were $\mathrm{y}=0.35 \mathrm{x}+6.83$ and $\mathrm{y}=1.30 \mathrm{x}$. The LSR had a slope similar to that of the Hassik model $(y=0.37 x+4.09)$ but with a larger intercept value, while the BL slope exceeded that of the Feng forest model $(\mathrm{y}=1.07 \mathrm{x})$.

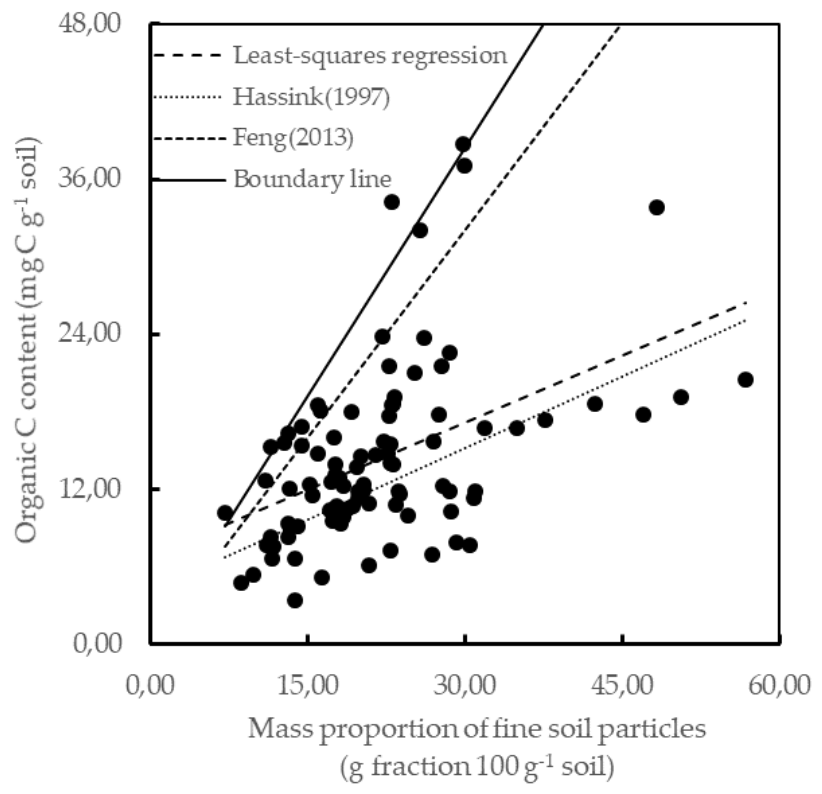

Figure 2. Scatterplot of soil organic carbon in karst forest as a function of the amount of fine soil particles examined with four linear modeling approaches 
Table 3. Estimated maximal organic $C$ stabilized by soil fine particles as determined by the slope of least-squares linear regression (LSR), the Hassink (1997) model, boundary line analysis (BL), and the Feng (2013) forest model

\begin{tabular}{c|c|c|c|c|c}
\hline Method & Slope $^{\mathbf{b}}$ & Intercept $^{\mathbf{b}}$ & $\mathbf{R}^{\mathbf{2}}$ & $\mathbf{P}$ & $\mathbf{N}^{\mathbf{a}}$ \\
\hline Hassink (1997) & 0.37 & 4.09 & 0.89 & 0.001 & 40 \\
LSR & $0.35 \pm 0.01$ & $6.83 \pm 0.38$ & 0.32 & $<0.01$ & 30 \\
\hline Feng (2013) & $1.07 \pm 0.08$ & - & 0.98 & 0.0058 & 3 \\
BL & $1.30 \pm 0.01$ & - & 0.96 & $<0.01$ & 3 \\
\hline
\end{tabular}

${ }^{a}$ Only data points from the top tenth percentile of organic $\mathrm{C}$ content were included in the BL analysis, ${ }^{\mathrm{b}}$ Slopes and intercepts are reported as the mean $\pm \mathrm{SE}$

\section{Modeling of maximal SOC saturation capacity}

The maximum saturated capacity of the SOC for the karst forest sites was estimated using the Hassink and Feng models along with the LSR and BL models. Data on the organic $\mathrm{C}$ content and mass proportion of soil fine particles at 30 sampling point locations (across all 30 plots of the 10 sites) were verified and analyzed (Table 4). Overall, 17, 12, and 5 samples were over-saturated, corresponding to $56.7 \%, 40.0 \%, 16.7 \%$ of the data fitted by the Hassink model, LSR, and Feng model, respectively. In contrast, when fitted by the BL model, the proportion of soil samples over-saturated was only 3.3\%.

Table 4. Over-saturation of organic C content of soil fine particles by comparing the measured maximal organic $C$ to predicted maximal organic $C$, estimated using least-squares linear regression (LSQ), the Hassink (1997) model, boundary line analysis (BL), and the Feng (2013) forest model

\begin{tabular}{c|c|c|c|c}
\hline Method & Land use & Total sample size & Over-saturated sample size & Over-saturated ratio (\%) \\
\hline Hassink (1997) & Forest & 30 & 17 & 56.7 \\
LSQ & Forest & 30 & 12 & 40.0 \\
Feng (2013) & Forest & 30 & 5 & 16.7 \\
BL & Forest & 30 & 1 & 3.3 \\
\hline
\end{tabular}

\section{Discussion}

There was no significant difference in the proportion of total organic $\mathrm{C}$ represented by fine particle $\mathrm{C}$ among the 10 sampled karst forest climax communities. This result indicates that the SOC tends to be stable, as expected. In this study, the maximum saturated capacity of SOC in karst forests in China was determined using the Hassink, Feng, LSR, and BL models. Of the four models, the BL model had the least over-saturated capacity, at 3.3\%; this value was 5-15 times higher for the other three models. Hence, the BL model is suitable for estimating the maximum saturated capacity of SOC in karst forest, and the other models should not be used for this application in this region. 
There are several reasons for the above-mentioned interpretation. First, available field studies of soil types are generally inconsistent. Hassink (1997) and Feng (2013) respectively studied farmland and natural grassland. The level of human disturbance activity incurred by farmland soil is substantial, and the fine particle organic $\mathrm{C}$ in these systems is severely damage or even destroyed. By contrast, the natural grassland soil fluctuates greatly, as it is in an early stage of vegetation succession for which the SOC stability is poor. However, the current study takes the climax forest community with less man-made disturbance in karst nature reserves as the research object. In these protected areas, the soil fine particle organic $\mathrm{C}$ is less prone to degradation from anthropogenic disturbances; thus, the SOC tends to be more stable. Karst forest is a unique forest ecosystem, one that is distributed on karst landforms. Due to the influence of the bedrock, a karst forest ecosystem is formed in a habitat of neutral to slightly alkaline lime soils rich in calcium and magnesium ions, whose distribution is restricted by soil topography (Zhou, 1987; Yu, 1998). Compared with farmland and grassland ecosystems on non-karst terrain, this special and complex forest ecosystem differs tremendously in terms of its ecological environment and plant-soil-water dynamics (Lal et al., 2007; Wei et al., 2008; Luo et al., 2017; Lin et al., 2019). At the same time, because the soil layer in karst forests is thin, the gravel content is high, and the SOC storage is low. By contrast, the farmland and grassland soil in non-karst zones have thick surface soil layers capable of high $\mathrm{C}$ storage.

Much research has proven that about half of the SOC is combined with soil minerals (Elliott et al., 1996; Ge, 2008; Pan et al., 2009). Calcium and oxidizable organic C are mainly accumulated in the form of calcium-bonded organic $\mathrm{C}$ to form a stable calciumbonded complex in the calcium-rich karst soil, which limits the contact between soil $\mathrm{C}$ and soil enzymes and degradable microorganisms. In this way, SOC is protected from microbial degradation and is conducive to the long-term accumulation of SOC. In calcium-rich calcareous soil environments, soil microbial activity is extremely active $\mathrm{Hu}$ et al., 2011; Tian et al., 2016; Guan et al., 2019), fostering the rapid decomposition of organic matter into humus. Many calcium ions can easily combine with this humus in the soil to form highly condensed and stable humus calcium substrate, which improves the overall stability of karst SOC, a view that is consistent with our modeling results $(y=1.30 x)$. Compared with the Hassink and Feng models, the slope of this model $(y=1.30 x)$ is the highest, indicating that with each per-unit increase of the mass proportion of fine particles, the SOC increases more rapidly and tends to more quickly reach a stable state, a process arguably related to the soil calcium in the karst forest. Therefore, models that are suitable for predicting maximum saturated capacity of SOC in farmland and grassland in non-karst zones are inadequate for use in karst forest.

Second, the Hassink model has some disadvantages (West et al., 2007; Feng et al., 2013; McNeill et al., 2014). Notably, it assumes that the regression line represents the maximum saturation capacity, which means that all the sample data that generate the regression line must lie close to the maximum stability of SOC (Six et al., 2000, 2002; Stewart et al., 2007, 2008, 2009, 2012). If the C content of soil fine particles does not 
reach the maximum value, then it is unreasonable to use this method to predict the maximum saturation capacity of SOC. In Hassink's study, although the uncultivated farmland and grassland soil were used as research objects, the degree of $\mathrm{C}$ saturation for each of the data building regression models was not mentioned (Carter et al., 2002; Chung et al., 2008, 2010). Further, the regression line of the Hassink model is forced through the middle of all the data points in the bivariate regression, representing the average, which tends to leave a considerable portion above the regression line over-saturated; this latter outcome is inconsistent with the actual expected estimation of the maximum saturation capacity of SOC (Virto et al., 2008, 2010; Feng et al., 2013; McNeill et al., 2014). As such, the Hassink model seriously underestimates SOC capacity. In this study, we used empirical data interspersed across 10 sites to analyze the Hassink model, finding that it yields the most over-saturated data, amounting to $56.7 \%$.

In the Feng model, only the data of fine particle $\mathrm{C}$ lying above a $10 \%$-threshold for the maximum stability of SOC were used to carry out regression analysis, and a maximum saturated capacity model of SOC was established (Elliott et al., 1996; Schuman et al., 2002; Tong et al., 2014). Compared with the LSR, the slope of this model is larger, because its intercept is zero (i.e., forced through the origin), thus leaving much data below the fitted regression line, which reduces the occurrence of over-saturation. In our verification analysis, the over-saturated data of the Feng model reached 16.7\%, perhaps because of between-site habitat differences or pronounced within-site heterogeneity (Tian et al., 2016; Guan et al., 2019). With only 3.3\% of the data over-saturated according to the BL model, we conclude the BL model is a relatively robust method for estimating the maximum saturated capacity of SOC. Nevertheless, estimations based on this model could also differ depending on the karst forest area and regional scales investigated (Zhang et al., 2010, 2012; Di, 2017).

\section{Conclusions}

Using comparative analysis and data verification of the Hassink model, Feng model, LSR, and BL model, we derived a maximum saturated capacity model of SOC for karst forest; the model exhibits a simple form: $y=1.30 x$. Although this model can be used to estimate the maximum saturated capacity of SOC in karst forest, we did not consider the effects of calcium carbonate and other exogenous substances on SOC in the studied karst areas. In future work, it is necessary to study the key soil characteristics and main mechanisms (calcium carbonate) that affect the stability of SOC, as well as any biochemical factors that could limit the stabilization rate of organic $\mathrm{C}$, so as to improve our ability to estimate the maximum saturated capacity of SOC in karst forests in China.

Author contributions. L.Z. and Y.W. analyzed the data and wrote the manuscript. L.Z. and Y.W. performed the experiments. J.C. participated in data analysis. L.Y. provided helpful suggestions in design of the project. L.Y. conceived and designed the project. All authors read and approved the final manuscript. 
Acknowledgments. Funding was provided by the Project of National Key Research and Development Program of China (grant number 2016YFC0502604); the Application Foundation Major Project of Guizhou Province (Qian Ke He JZ [2014] 2002); the Construction Program of Biology First-class Discipline in Guizhou (GNYL [2017]009); and the Project of Promoted Innovation of Colleges and Universities of Guizhou Province (Qian Jiao He Collaborative Innovation [2014]01).

Conflict of Interests. The authors declare no conflict of interests.

\section{REFERENCES}

[1] Angers, D. A., Arrouays, D., Saby, N. P. A., Walter, C. (2011): Estimating and mapping the carbon saturation deficit of French agricultural topsoils. - Soil use and management 27(2): 448-452.

[2] Banger, K., Kuka, S. S., Toor, G., Sudhir, K., Hanumanthraju, T. H. (2009): Impact of long-term additions of chemical fertilizers and farmyard manure on carbon and nitrogen sequestration under rice-cowpea cropping system in semi-arid tropics. - Plant and soil 31(4): 27-35.

[3] Bastida, F., García, C., Fierer, N., Eldridge, D. J., Cutler, N. A. (2019): Global ecological predictors of the soil priming effect. - Nature communications 10(2): 3481.

[4] Carter, M. R. (2002): Soil quality for sustainable land management: Organic matter and aggregation interactions that maintain soil function. - Agronomy Journal 94: 38-47.

[5] Chen, L. Y., Liu, L., Qin, S. Q., Yang, G. B., Fang, K., Xu, Y. P., Yang, Y. H. (2019): Regulation of priming effect by soil organic matter stability over a broad geographic scale. - Nature communications 10(2): 5112.

[6] Chung, H., Grove, J. H., Six, J. (2008): Indications for soil carbon saturation in a temperate agroecosystem. - Soil Science Society of America Journal 72(3): 1132-1139.

[7] Chung, H., Ngo, K. J., Plante, A., Six, J. (2010): Evidence for carbon saturation in a highly structured and organic matter rich soil. - Soil Biology and Biochemistry 74(4): 130-138.

[8] Di, J. Y. (2017): Characteristics and driving factors of carbon saturation deficit in typical cropland in China. - Postdoctoral dissertation of Chinese academy of agricultural sciences.

[9] Di, J. Y., Xu, M. G., Zhang, W. T., Tong, X. G., He, X. H., Gao, H. J., Liu, H., Wang, B. R. (2018): Combinations of soil properties, carbon inputs and climate control the saturation deficit dynamics of stable soil carbon over 17-year fertilization. - Scientific Reports 8: 110.

[10] Ding, X. L., Han, X. Z., Qiao, Y. F., Li, L. J., Li, N., Song, X. J. (2012): Sequestration of organic carbon in cultivated soils: Main factors and their stabilization mechanisms. Chinese Journal of Soil Science 43: 737-744.

[11] Dixon, R. K., Solomon, A. M., Brown, S., Houghton, R. A., Trexier, M. C., Wisniewski, J. (1994): Carbon pools and flux of global forest ecosystems. - Science 263: 185-190.

[12] Elliott, E. T., Paustian, K., Frey, S. D. (1996): Modeling the measurable or measuring the modelable: A hierarchical approach to isolating meaningful soil organic matter fractionations. - Evaluation of soil organic matter models 38: 161-179. NATO ASI Series, Springer-Verlag.

[13] Feng, W. T., Plante, A. F., Six, J. (2013): Improving estimates of maximal organic carbon stabilization by fine soil particles. - Biogeochemistry 112(3): 81-93.

[14] Ge, Y. J. (2008): Organic carbon mineralization and microbial in typical Karst soil as a response to the exogenous addition of calcium carbonate and organic substrate. - Master dissertation of Hunan agricultural university. 
[15] Guan, J. H., Deng, L., Zhang, J. G., He, Q. Y., Shi, W. Y., Li, G. Q., Du, S. (2019): Soil organic carbon density and its driving factors in forest ecosystems across a northwestern province in China. - Geoderma 35(2): 1-12.

[16] Guo, J. H., Liu, X. J., Zhang, Y. (2016): Significant acidification in major Chinese croplands. - Science 372: 1008-1010.

[17] Hassink, J. (1997): The capacity of soils to preserve organic C and $\mathrm{N}$ by their association with clay and silt particles. - Plant and Soil 191(2): 77-87.

[18] Houghton, R., Lawrence, K., Hackler, J., Brown, S. (2001): The spatial distribution of forest biomass in the Brazilian Amazon: a comparison of estimates. - Global Change Biology 7(2): 731-746.

[19] Hu, L. N., Su, Y. R., He, X. Y., Li, Y., Wu, J. S. (2011): Effect to the turnover of soil organic carbon in three typical soils in karst area by adding ${ }^{14} \mathrm{C}$-labelled organic matter. Journal of agro-environment science 30(5): 2368-2373.

[20] Hu, X. M., Lou, Y. L., Hu, N. (2016): Community size, activity and C:N stoichiometry of soil microorganisms following reforestation in a Karst region. - European Journal of Soil Biology 73(3): 77-83.

[21] Jing, X., Chen, X., Fang, J. Y., Ji, C. J., Shen, H. H., Zheng, C. Y., Zhu, B. (2020): Soil microbial carbon and nutrient constraints are driven more by climate and soil physicochemical properties than by nutrient addition in forest ecosystems. - Soil biology and biochemistry 141: 107657.

[22] Lal, R., Follett, F., Stewart, B. A., Kimble, J. M. (2007): Soil carbon sequestration to mitigate climate change and advance food security. - Soil Science Society of America Journal 172(2): 943-956.

[23] Li, D. J., Xiao, K. C., He, T. G. (2017): Impacts of vegetation restoration strategies on soil organic carbon and nitrogen dynamics in a karst area, southwest China. - Ecological Engineering 101(3): 247-254.

[24] Liang, A. Z., Yang, X. M., Zhang, X. P. (2009): Soil organic carbon changes in particlesize fractions following cultivation of black soils in China. - Soil and tillage research 105(1): 21-26.

[25] Lin, W. Q., Gao, W., Ye, G. F., Huang, S. D., Huang, Y. R., Yue, X. J. (2019): Litter nutrient return of different plantations in a coastal sand dune of southern subtropical region. - Journal of forest and environment 39(3): 225-231.

[26] Liu, A. X-J., Finley, B. K., Mau, R. L., Schwartz, E., Dijkstra, P., Bowker, M. A., Hungate, B. A. (2020): The soil priming effect: Consistent across ecosystems, elusive mechanisms. - Soil biology and biochemistry 140(3): 107617.

[27] Lu, X. Q., Hiroto, T., Ding, F. J. (2014): Effect of vegetation types on chemical and biological properties of soils of karst ecosystems. - European Journal of Soil Biology 62(2): 49-57.

[28] Luo, Z. K., Feng, W. T., Luo, Y. Q., Baldock, J., Wang, E. L. (2017): Soil organic carbon dynamics jointly controlled by climate, carbon inputs, soil properties and soil carbon fractions. - Global Change Biology 10(2): 128-134.

[29] Luo, R. Y., Kuzyakov, Y., Liu, D. Y., Fan, J. L., Luo, J. F., Lindsey, S., He, J. S., Ding, W. X. (2020): Nutrient addition reduces carbon sequestration in a Tibetan grassland soil: Disentangling microbial and physical controls. - Soil biology and biochemistry 144(1): 107764.

[30] McNeill, S. J., Curtin, D., Parfitt, R. L., Dodd, M. B. (2014): Estimating the organic carbon stabilisation capacity and saturation deficit of soils. - A New Zealand case study: Biogeochemistry 120(2): 71-87.

[31] Pan, G., Zhao, Q. G. (2005): Study on evolution of organic carbon stock in agricultural soils of China: Facing the challenge of global change and food security. - Advance in Earth Sciences 20(1): 384-493. 
[32] Pan, G., Smith, P., Pan, W. (2009): The role of soil organic matter in maintaining the productivity and yield stability of cereals in China. - Agriculture, Ecosystems and Environment 129(2): 344-348.

[33] Rillig, M. C., Ryo, M., Lehmann, A., Buchert, S., Wulf, A., Lwasaki, A., Roy, J., Yang, G. W. (2019): The role of multiple global change factors in driving soil functions and microbial biodiversity. - Science 366: 886-890.

[34] Schlesinger, W. H. (1990): Evidence from chronosequence studies for a low carbon-storage potential of soils. - Nature 348: 232-234.

[35] Schuman, G. E., Janzen, H. H., Herrick, J. E. (2002): Soil carbon dynamics and potential carbon sequestration by rangelands. - Environmental Pollution 116(4): 391-396.

[36] Six, J., Elliott, E. T., Paustian, K., Doran, J. W. (2000): Aggregation and soil organic matter accumulation in cultivated and native grassland soils. - Soil Science Society of America Journal 62(4): 1367-1377.

[37] Six, J., Conant, R. T., Paul, E. A., Paustian, K. (2002): Stabilization mechanisms of soil organic matter: Implications for C-saturation of soils. - Plant and Soil 241(5): 155-176.

[38] Stewart, C. E., Paustian, K., Conant, R. T., Plante, A. F., Six, J. (2007): Soil carbon saturating: concept, evidence and evaluation. - Biogeochemistry 86(3): 19-31.

[39] Stewart, C. E., Plante, A. F., Paustian, K., Conant, R. T., Six, J. (2008): Soil carbon saturation: linking concept and measurable carbon pools. - Soil Science Society of American Journal 72(2): 379-392.

[40] Stewart, C. E., Paustian, K., Conant, R. T., Plante, A. F., Six, J. (2009): Soil carbon saturation: implications for measurable carbon pool dynamics in long-term incubations. Soil Biology and Biochemistry 41(3): 357-366.

[41] Stewart, C. E., Follett, R. F., Wallace, J., Pruessner, E. G. (2012): Impact of biosolids and tillage on soil organic matter fractions: Implications of carbon saturation for conservation management in the Virginia coastal plain. - Soil Science Society of America Journal 76(3): 1257-1267.

[42] Su, Y. R., Liang, Y. M., He, X. Y. (2015): Influence of plant communities and soil properties during natural vegetation restoration on arbuscular mycorrhizal fungal communities in a karst region. - Ecological Engineering 82(4): 57-65.

[43] Tian, Q. X., He, H. B., Cheng, W. X., Bai, Z., Wang, Y., Zhang, X. D. (2016): Factors controlling soil organic carbon stability along a temperate forest altitudinal gradient. Scientific Reports 26(3): 1-9.

[44] Tong, X. G., Xu, M. G., Wang, X., Bhattacharyya, R., Zhang, W. J., Cong, R. H. (2014): Long-term fertilization effects on organic carbon fractions in a red soil of China. - Catena 11(3): 251-259.

[45] Trumbore, S. (2006): Carbon respired by terrestrial ecosystems-recent progress and challenges. - Global Change Biology 12(2): 141-153.

[46] Virto, I., Barre, P., Chenu, C. (2008): Microaggregation and organic matter storage at the silt-size scale. - Geoderma 146(2): 326-335.

[47] Virto, I., Moni, C., Swanston, C., Chenu, C. (2010): Turnover of intraand extra-aggregate organic matter at the silt-size scale. - Geoderma 156: 1-10.

[48] Wang, K. L., Liu, S. J., Zhang, W. (2015): Factors controlling accumulation of soil organic carbon along vegetation succession in a typical karst region in Southwest China. - Science of the Total Environment 521(2): 52-58.

[49] Wei, Y. (2008): Study on the biological characteristics of soil quality in succession processes of degraded karst vegetation-A case study at Huajiang of Guizhou. - Doctoral dissertation of Nanjing forestry university.

[50] West, T. O., Tristram, O., Six, J. (2007): Considering the influence of sequestration duration and carbon saturation on estimates of soil carbon capacity. - Climatic Change 80: $25-41$. 
[51] Williams, S. T., Gray, T. G. (1974): Decomposition of litter on soil surface. - In: Dickinson, C. H., Pugh, G. J. E. (eds.) Biology of plant litter decomposition. Academic Press, London and New York, pp. 611-632.

[52] Yu, L. F. (1998): A study on the natural restoration ecological process of degraded karst forests. - Doctoral dissertation of Nanjing forestry university.

[53] Zhang, W. J., Xu, M. G., Wang, X. J., Huang, S. M., Liu, H., Peng, C. (2010): Soil organic carbon dynamics under long-term fertilizations in arable land of northern China. Biogeosciences 7(2): 409-425.

[54] Zhang, W. J., Xu, M. G., Wang, X. J., Huang, Q. H., Nie, J., Li, Z., Lee, K. B. (2012): Effect of organic amendments on soil carbon sequestration in paddy fields of subtropical China. - Soils Sediments Journal 12(3): 457-479.

[55] Zhang, L. M., Xu, M. G., Lou, Y. L., Wang, X. L., Qin, S., Jiang, T. M., Li, Z. F. (2014): Changes in yellow paddy soil organic carbon fractions under long-term fertilization. Scientia Agricultura Sinica 47(1): 3817-3825.

[56] Zhou, Z. X. (1987): Scientific survey of the Maolan karst forests. - Guihou Science and Technology Press, pp. 1-23.

[57] Zhu, J. X., Hu, H. F., Tao, S. L., Chi, X. L., Li, P., Jiang, L., Ji, C. J., Zhu, J. L., Tang, Z. Y., Pan, Y. D., Birdsey, R. A., He, X. H., Fang, J. Y. (2017): Carbon stocks and changes of dead organic matter in China's forests. - Nature Communication 8: 1-10. 